\title{
The management of informal settlements for urban sustainability: experiences from the Campania Region (Italy)
}

\author{
F. Forte \\ Department of Architecture and Industrial Design "Luigi Vanvitelli", \\ Second University of Naples, Italy
}

\begin{abstract}
A particular and worrying form of urbanization are "informal settlements" or unauthorised buildings (abusivismo edilizio), a phenomenon which is particularly accentuated in southern Italian cities, especially in Campania Region. Nevertheless their challenges - economic, social and environmental - have been widely recognized in international and national programs fostering urban sustainability. In Italy, as in other European countries, the actions set out by current regulations to address illegal settlements follow several approaches: repressive, mitigatory and comprehensive. This last approach provides the legalization of informal settlements or buildings on the basis of a pecuniary sanctions to obtain a "retrospective building permit".

The sanctions could represent a significant item of revenue and capital expenditure (or investment) in financing the public city. In this perspective, the article wants to extend the question with reference to some cities of the Campania Region, where there are numerous types of informal settlements. Considering the different assessment procedures used by municipalities in order to determine the value of illegal works and analyzing some municipal budgets, both the efficiency and effectiveness of this tool will be evaluated, as well as the capability of local authorities in the informal settlements management for the promotion of sustainable city.
\end{abstract}

Keywords: informal settlements management, urban sustainability, local finance, municipal budgets, evaluation. 


\section{Introduction}

Today, according to The World Urbanization Prospect: The 2014 Revision [1], over half of the world's population $-54 \%$ - lives in urban areas, with one of the most urbanized regions being Europe, where more than $73 \%$ of its population lives in cities, towns and suburbs (in Northern America 82\% and in Latin America and Caribbean 80\%). Urbanization in Europe is an ongoing phenomenon both in terms of urban land expansion and increasing population share, along with its impacts extending beyond city borders [2].

A particular and worrying form of urbanization is representing by unplanned urban development, frequently characterized by informal settlements or unauthorized buildings, especially in the east and south of Europe [3]. However, its challenges - economic, social and environmental - have been widely recognized in international and national programs fostering urban sustainability.

The concept of urban sustainability is there intended in a more wide perspective, as proposed by Allen and You in 2002 [4], with it including the five dimensions of sustainability and their relationships: economic, social, ecological, physical and political dimensions. In particular, physical sustainability or the sustainability of built environment "concerns the capacity of an intervention to enhance the liveability of buildings and urban infrastructures for 'all' city dwellers without damaging or disrupting the urban region environment. It also includes a concern for the efficiency of the built environment to support the local economy" [5].

In this perspective, the informal settlements or unauthorized housing are part of the built environment, mobilizing those investments that remain outside of the formal economy and investment cycles, thus constituting a particular form of valuable capital assets, as well highlighted by De Soto [6].

Generally, the definition of informal settlement is strictly connected to the context, depending on the planning and legal framework of a country where this phenomenon appears; in this study, we adopt the significance given by the UNHabitat Program, since it is the most widely applicable: informal settlements are residential areas where a group of housing units has been constructed on land to which the occupants have no legal claim or which they occupy illegally or unplanned settlements as well as areas where housing is not in compliance with current planning and building regulations (unauthorized housing).

In Italy the phenomenon of informal settlements (the "first generation") is a serious and very old problem that three amnesties for the infringement of local building regulations (the last in 2003) could not solve it; the phenomenon is prevalently in form of unauthorized housing or illegal buildings, "in areas frequently inhabited by low or middle class families, in housing construction of modest (sometime good) quality, often on legally owned land. The illegal nature of these developments is associated with the lack of formal urban plans and/or building licenses" [7].

Considering that the phenomenon is particularly accentuated in southern Italian, especially in the Campania Region and assuming that it is no longer possible to continue to ignore financial tools that may allow for the recovery of 
liveability for the community that is widely impaired, the article aims to deal with the argument from the perspective of local finance. The article is organized as follows: Section 2 will offer a concise overview of the informal settlements in the Campania Region; Section 2.1 will address the issue of the assessment of pecuniary sanctions in order to obtain retrospective building permits, analyzing the different procedures. Then, Section 3 will introduce the question of the management of informal settlements from a municipal finance perspective, exploring, in Section 3.1, two different municipal budgets. The paper ends with some concluding remarks.

\section{Informal settlements in Campania Region (Italy)}

Despite the "promotion of the sustainable development of urban and extra-urban territory trough the minimum soil consumption" being one of the main goals of the Campania Regional Law on Territory Government (Law 16/2004), the intense urbanization process, frequently chaotic and unplanned which has involved for a long time the regional territory and, above all, the urban area of Naples (Figure 1) seems to contradict this attempt.

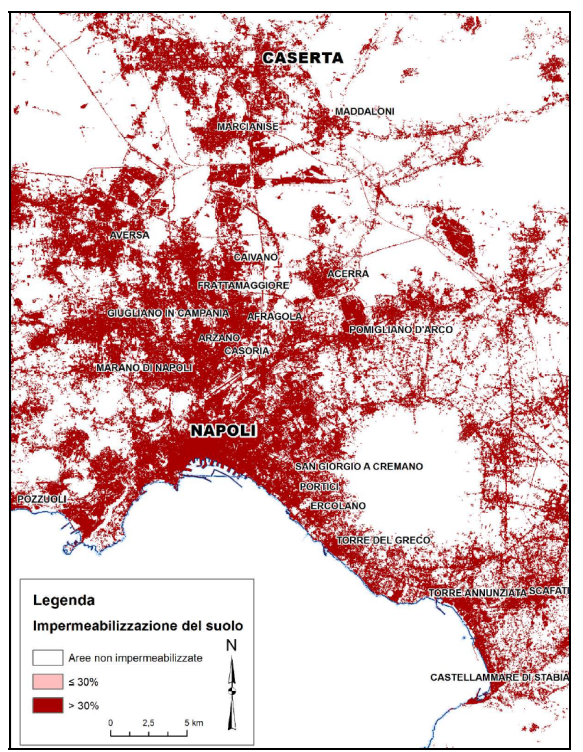

Figure 1: $\quad$ Soil sealing in the urban area of Naples [8].

A useful indicator for understanding the evolution of this process is represented by the size of building permits (the authorisation required to build or transform existing buildings, issued by the municipality on submission of the project) released in the last years that remain consistent in all the five provinces of the Region, as in Table 1, despite the decrease recorded in the latest official available data for new buildings. 
Table 1: Building permits in the five provinces of the Campania Region.

\begin{tabular}{|c|c|c|c|c|c|c|c|c|c|c|c|c|}
\hline \multirow{2}{*}{ Provinces } & \multicolumn{2}{|c|}{2007} & \multicolumn{2}{|c|}{2008} & \multicolumn{2}{|c|}{2009} & \multicolumn{2}{|c|}{2010} & \multicolumn{2}{|c|}{2011} & \multicolumn{2}{|c|}{2012} \\
\hline & Buildings & Dwellings & Buildings & Dwellings & Buildings & Dwellings & Buildings & Dwellings & Buildings & Dwellings & Buildings & Dwellings \\
\hline Caserta & 740 & 3.865 & 601 & 2.249 & 537 & 2.059 & 457 & 1.576 & 505 & 1.890 & 393 & 1.143 \\
\hline Benevento & 158 & 602 & 277 & 889 & 192 & 571 & 164 & 477 & 162 & 495 & 114 & 300 \\
\hline Napoli & 602 & 3.602 & 387 & 1.989 & 498 & 2.466 & 484 & 2.007 & 524 & 1.957 & 565 & 1.891 \\
\hline Avellino & 348 & 1.009 & 279 & 1.000 & 289 & 1.168 & 198 & 537 & 274 & 817 & 176 & 514 \\
\hline Salerno & 609 & 2.409 & 606 & 2.163 & 493 & 1.637 & 355 & 1.284 & 501 & 1.640 & 400 & 1.194 \\
\hline Campania & 2.457 & 11.487 & 2.150 & 8.290 & 2.009 & 7.901 & 1.658 & 5.881 & 1.966 & 6.799 & 1.648 & 5.042 \\
\hline
\end{tabular}

Conjointly with the dynamics of authorized buildings, the process of building pressure is increased by the informal settlements phenomenon that, in addition to the legal issues, has a strong territorial impact, with relevant effects on the individual and collective welfare (urban sustainability, quality of life, safety, etc.). In the BES - Benessere Equo e Solidale - Report [9], an outcome of a national project aims to measure equitable and sustainable well-being inside the international debate on "GDP and beyond", the index of illegal building (ratio of the number of unauthorized buildings to the number of building permits issued by the Municipalities) in the South of Italy and the Islands has recently risen over $35 \%$, as in Table 2 .

Table 2: The index of illegal building in Italy.

\begin{tabular}{|l|c|}
\hline Italian Regions & $\begin{array}{c}\text { Illegal building rate } \\
\mathbf{2 0 1 3}\end{array}$ \\
\hline Northern Italy & $\mathbf{5 , 3}$ \\
\hline Piemonte & 4,4 \\
Valle d'Aosta & 4,4 \\
Ligury & 15,3 \\
Lombardy & 5 \\
Trentino-Alto Adige & 1,6 \\
Veneto & 6,8 \\
Friuli-Venezia Giulia & 4,4 \\
\hline Central Italy & $\mathbf{1 1 , 6}$ \\
\hline Emilia-Romagna & 5,4 \\
Tuscany & 10,8 \\
Umbria & 14,9 \\
Marche (The Marches) & 8,7 \\
Lazio (Latium) & 12,2 \\
Abruzzo & 27,4 \\
Molise & 49,4 \\
\hline Southern Italy and Islands & $\mathbf{3 5 , 9}$ \\
\hline Campania & 62,1 \\
Puglia (Apulia) & 21,7 \\
Basilicata & 29,5 \\
Calabria & 69,3 \\
Sicilia (Sicily) & 47,7 \\
Sardegna (Sardinia) & 21,2 \\
\hline
\end{tabular}

Specifically in the Campania Region, where the maximum intensity of the phenomenon has been recorded (after the Calabria Region), it has been estimated that the share of illegal buildings is almost equal to half of those built legally.

The provinces of Naples and Caserta are the most affected by this problem, with many small and medium sized towns having lost their administrative boundaries, while the peri-urban areas are frequently transformed for urban uses by landowners, without any official planning permission and licenses. 
These settlements, where the residential component prevails, are characterized by a low level of physical quality, scarcity of standards and public facilities, compromising territories with a strong rural and agricultural vocation or coastal areas of environmental value. It is not by chance that many municipalities in both provinces are under judicial administration as a consequence of illegal building practices. The framework becomes even more complex considering the number of cases that are waiting to be examined in order to granted the amnesty; in the meanwhile, most of the buildings remain with their owners with an anomalous cadastral classification "sanabile" buildings) and are put on the real estate property market to either rent or sell, constituting a particular form of "informal submarket" object of sanctions and, indeed, of appraisal [10].

There are numerous types of informal settlements in the Campania Region: illegal single-family houses or multi-family buildings within the city; illegal extensions in violation of building regulations; illegal buildings in protected areas with landscape and environmental constraints (as in the UNESCO sites) or in archeological areas (such as around the Appia Antica way); informal settlements in peri-urban areas, outside the municipality boundaries.

In this very common last type of informal settlement, the spatialmorphological and functional features prevalently take the form of variants of an elementary settlement typology structured on a schema in a comb shape, with a substantial homogeneity of building typologies, in prevalence mono or semidetached houses on parcels of a minimum extension and without any ordering rule.

In the city of Naples, one of the best known cases of informal settlement is the neighborhood of Pianura with 58 thousand inhabitants and 70 thousand applications for an amnesty. The buildings are illegal because they were built without any form of building permit, while also violating the zoning plan; but the land was legally bought by private developers who respected the building standards, and homes were placed on the market at prices only slightly (15-20\%) below the cost of legal units [11]. While, in the province of Naples, one of the best known cases of informal settlements and unauthorized buildings is Giugliano in Campania; there, the rapid population increase has caused an unplanned development, especially in the suburbs.

In the Caserta Province, according to the Territorial Plan (approved in 2012), approximately 12,000 hectares has been built in absence of the Master Plans and the maximum concentration is in the Caserta and Aversa conurbation as well as along the Domitian coast.

\subsection{Informal settlements and the assessment of pecuniary sanctions}

As in other European countries, in Italy the actions set out by current regulations to address illegal settlements follow several approaches: a repressive approach that concerns the demolition of illegal structures (frequently disregarded); a mitigatory approach, that consists in the confiscation of properties and their regeneration by means a detailed urban plan and a comprehensive approach that 
provides the legalization of informal settlements or buildings on the basis of a pecuniary sanctions to obtain a "retrospective building permit".

The sanctions are established on the basis of Presidential Decree No. 380/2001, the so called Testo Unico dell'Edilizia, which provides building activities regulations and could represent a significant item of revenue and capital expenditure or "investment" in financing the public city. Considering the informal settlements phenomenon, this opportunity of financial recovery should not be underestimated, as has happened up until now, especially in light of the disastrous effects of the current economic recession on the budgets of local authorities, which are forced to deal with increasingly limited resources and an increasingly challenging internal stability pact.

The building pecuniary sanction can be proportional to the value of the illegal building or contraventional, determined on the basis of a minimum and a maximum. The proportional pecuniary sanction is prescribed by law when it is impossible to restore the status quo through demolition, both in the case of a building realized ex novo, in absence of a building permit or in total dissimilarity with it and in the case of an intervention of renewal without a building permit or in dissimilarity with it.

The procedures for the assessment of the sanctions are different. In the case of the renewal of a building for residential use in absence of a building permit, or in total dissimilarity with it, the amount of the sanction is equal to the double of the increase of the building value resulting with the realization of the illegal works (the evaluation criterion is finalized to determine the production cost of the part of the building realized illegally; this cost is doubled).

For the buildings with a non-residential use, the sanction is established with reference to the market value estimated by the Cadastral Office. In the case of interventions realized in partial dissimilarity with the building permit, or in absence of the statement of the start of works or differently from it, the sanction is equal to the double of the production cost of the part realized dissimilarity to the permit if for residential use and to the double of the increase of the building value for the works concerning other destinations.

In the case of interventions realized without a building permit, or in dissimilarity with it or in absence of the statement of the start of works, whoever is responsible for the illegal works or the actual owner of the building can obtain the permit "in sanatoria" or the retrospective building permit. This can happen if the interventions are in compliance with the planning and buildings rules in force both at the time of the realization of the building and at the time of presenting the application. However, in order to get the "sanatoria", an amount equal to the double of contribution of construction (art. 16, Presidential Decree No. 380/2001) must be paid. This contribution is paid so as to obtain the building permit and is commeasured with the incidence of urbanization charges (determined by the municipalities on the basis of the regional parametric tables) and construction costs, determined by the Regions periodically.

A different form of sanction concerns illegal buildings in protected areas with landscape and environmental constraints. The Italian Code of the Cultural and Landscape Heritage (art. 167, Legislative Decree n. 42/2004) ascertains that, in 
case of violation of the obligations and orders, the transgressor shall be obliged to restore the cultural property to its original state at his own expense or "pay a sum equivalent to the greater amount between the damage caused and the profit derived through the transgression".

The sum is determined by the Municipality on the basis of an official assessment and shall be utilised for safeguarding purposes, works for reclamation of landscape values and the upgrading of deteriorated areas. There are several procedures adopted by municipalities in order to determine the value of illegal work: some of them are referred to the cadastral value (established by Agenzia delle Entrate for property tax); others are based on the difference between the value of illegal works and the cost sustained for its realization; eventually, other procedures adopt criteria of pre-existent and old norms.

Prevalently, the sanction for the indemnity is assessed through a purely financial criterion and the limit of these assessment procedures is the exclusion of the immaterial or intangible values that characterize the environmental and historical heritage. In the perspective of sustainability, a more integrated and multidimensional approach for the evaluation of environmental damage occurs [12], considering the socio-economic relevance that disruption, deterioration or alteration produce to the environment, in the widest meaning of the term.

\section{Local finance and management of informal settlements}

Nowadays local finance plays a crucial role in the implementation of the Sustainable City. From an economic point of view, the promotion of the sustainable city - or the self-sustainable city - [13] could be seen as a productive activity aiming to transform the existing city into a city capable of selfregulating, enhancing (and not wasting) the existing resources, through the optimal combination of the production factors (the land; the capital and the labour, essential for realization or regeneration of infrastructure and buildings and the management capability of public and private subject in coordinating the different factors).

In this perspective, it is possible to identify the city or municipality (the local authority which represents its community) as an entrepreneur subject whose productive capability should be inspired by criteria of effectiveness, efficiency and inexpensiveness. This criteria, derived from business administration, have been incorporated definitively in the Italian Consolidated Act on Local Authorities (Legislative Decree no. 267/2000), which contains the financial principles of the Municipal Budget, understood as a programming and management tool. The importance of budgets has grown significantly as cities face increasingly difficult expenditure and revenue decisions in an environment of increased demands of services and infrastructure [14].

According to the Italian legal system, Local Authorities (or Municipalities) on the basis of territorial government rules - are concerned with planning and building matters and, above all, have the faculty to transform urban areas. The right or permission to build is given under the payment of a contribution of construction or "development charge". This contribution is inserted into the 
Municipal Budget, the tool that sets out the local government's plan for revenue and expenditure for an annual or multi-year period. The revenues from the issuing of "building permits" (the original former building permit or urbanization charges introduced by Italian Law 10/77, then modified in "contribution of construction" by Presidential Decree no. 380/2001) are constrained funds (together with the property tax) in the budget of the local authority to be used for financing the "public city" (such as the construction of primary and secondary urbanization works, urban facilities as well as the maintenance of the assets, green urban areas, etc.).

In addition, the revenues deriving from retrospective building permit or permit in sanatoria for the informal settlements are constrained funds, intended, among the other things, for the demolition of works that are not subject to the amnesty or sanatoria; for interventions of urban and environment regeneration; for the realization of primary and secondary urbanization works.

Both the revenues are registered in the Municipal Budget under Title IV, as in Table 3, but several financial laws during the last decade have contributed to distorting the original nature of these revenues, no longer exclusively finalized at capital expenditure or investments for the municipal infrastructure, but also for current expenditures, within the limit of $50 \%$ of the annual total.

Table 3: Municipal budget revenues and expenditures.

\begin{tabular}{|l|l|}
\hline \multicolumn{1}{|c|}{ REVENUES } & \multicolumn{1}{|c|}{ EXPENDITURES } \\
\hline CURRENT REVENUES & \multicolumn{1}{|c|}{ CURRENT EXPENDITURES } \\
Title 1 - Tax revenues & Title 1- Current Expenditures \\
Title 2 - Current transfers from other governments & \\
Title 3 - Current no tax revenues & \\
CAPITAL REVENUES & CAPITAL EXPENDITURES \\
Title 4 - Disposal of fixed assets, capital \\
transfers from other governments and private enities \\
- building permits and retrospective building permits \\
\hline $\begin{array}{l}\text { Title 5 - Borrowing Title 2 - Capital expenditures } \\
\text { Title 6 - Clearing entries }\end{array}$ & Title 3 - Loan repayments \\
\hline \multicolumn{1}{|c|}{ Total } & \multicolumn{1}{|c|}{ Totale 4 - Clearing entries } \\
\hline
\end{tabular}

Generally, the expenditures of local authorities are classified on the basis of four main titles with several functions (see Table 3) and are subdivided into current and capital expenditures.

In order to try to connect the local authority activity, measured by municipal cash flows, with some indicators of sustainability, analysing the environment dimension, in municipal budget, the expenditures for the environment are considered together with those for the management of the territory (function 9: Territory and Environment) and are classified as: Urban Planning and Territory, Social Housing, Civil Protection, Water Service, Waste and Parks.

Analysing the several voices that compose the municipal budget with specific reference to the final budget, it is possible understand how the resources are managed and, in particular, how the informal settlement phenomenon is managed; in this perspective will be developed the next paragraph. 


\subsection{Experiences from Campania Region}

Considering the informal settlement phenomenon, the failure of the Local Authorities has become evident to contrast its effects through the repressive approach, or a systematic demolition of illegal structures. In particular, in the Campania Region this approach has been frequently disregarded for several and complex reasons (political, social and financial); in the meantime, the difficulty of local authorities in financing public expenditures is well-known but it is also a paradox that the citizens have to pay property tax (always more expensive) on their legal buildings, while the citizens that do not respect the urban planning rules have built unauthorized structures without paying the construction contribution and do not even pay the tax (both local and national) on their illegal buildings. Therefore, the problem of illegal buildings that characterizes many municipalities, assumes a certain relevance if it is analyzed from a municipal finance perspective.

An analysis of the latest municipal budgets could help to evaluate both the efficiency and effectiveness of the retrospective building permit tool as well as the capability of local authorities in the management of informal settlements, understood as a consistent part of the built environment, whose sustainability also includes a concern for its efficiency to support the local economy (according to the concept of urban sustainability adopted in the introduction).

In this section, some analyses, started within a departmental research on informal settlements [15], are developed further; it is important underline that some of the information or data are not available in any institutional data bank on municipal bases; in particular, for the revenues deriving from the Title 4.05 "building permit and retrospective building permits" it is very difficult to deduce the differentiation between the two forms of revenue.

For example, it was chosen to explore two meaningful cases: the Municipality of Giugliano in Campania (in the Province of Naples) and the Municipality of Casal di Principe (in the Province of Caserta), two urban realities where the informal settlements phenomenon is particularly accentuated.

In the province of Naples the best known case of informal settlements and unauthorized buildings is Giugliano in Campania (120,545 inhabitants), the third municipality in Campania Region for the number of inhabitants; the rapid increase of population has caused an unplanned development, especially in the suburbs and along the coast, areas frequently characterized by the scarcity of infrastructures and public facilities.

The municipality of Casal di Principe (21,500 inhabitants), already object of analysis [16], is characterized by a strong deficiency of standard areas: the amount of planned public equipment should be 44.4 hectares, while the amount of existing public equipment is only 6.1 hectares; most of the $35 \%$ of the urbanized area is illegal, concentrated in the Agricultural Area, as identified in the Municipal Master Plan.

Analyzing the final budgets in the triennium 2011-2013, with specific reference to the revenues deriving from the Title 4.05 "building permit and retrospective building permit (or sanctions)", only in the municipal budget of 
Giugliano specified in the two entities for the year 2013 and 2012, on the basis of the data in the Tables 4 and 5, it is possible develop some considerations.

Table 4: Revenues from "building permit and sanctions" in Giugliano.

\begin{tabular}{|l|c|c|c|}
\hline \multicolumn{1}{|c|}{ Giugliano } & \multicolumn{2}{c|}{120.545 inhabitatnts } \\
\hline \multicolumn{1}{|c|}{ Revenues } & $\begin{array}{c}\mathbf{2 0 1 3} \\
\text { in } €\end{array}$ & $\begin{array}{c}\mathbf{2 0 1 2} \\
\text { in } €\end{array}$ & $\begin{array}{c}\mathbf{2 0 1 1} \\
\text { in } €\end{array}$ \\
\hline building permit & 932.979 & 1.109 .430 & \\
retrospective building permit & 2.080 .479 & 2.779 .490 & \\
\hline Total & $\mathbf{3 . 0 1 3 . 4 5 8}$ & $\mathbf{3 . 8 8 8 . 9 2 0}$ & $\mathbf{4 . 9 0 1 . 7 5 7}$ \\
\hline per capita & euro 25 & euro 32 & euro 41 \\
\hline
\end{tabular}

Table 5: Revenues from "building permit and sanctions" in Casal di Principe.

\begin{tabular}{|l|c|c|c|}
\hline \multicolumn{1}{|c|}{ Casal di Principe } & \multicolumn{3}{c|}{21.500 inhabitatnts } \\
\hline Revenues & $\begin{array}{c}\mathbf{2 0 1 3} \\
\text { in } €\end{array}$ & $\begin{array}{c}\mathbf{2 0 1 2} \\
\text { in } €\end{array}$ & $\begin{array}{c}\mathbf{2 0 1 1} \\
\text { in } €\end{array}$ \\
\hline $\begin{array}{l}\text { building permit together with } \\
\text { retrospective building permit }\end{array}$ & & & \\
\hline Total & $\mathbf{1 5 6 . 0 8 8}$ & $\mathbf{2 0 3 . 1 4 2}$ & $\mathbf{3 3 8 . 1 4 3}$ \\
\hline per capita & euro 7 & euro 9 & euro 16 \\
\hline
\end{tabular}

In both municipalities, the revenues show a significant decrease: in Giugliano in two years, the revenues have decreased by about $40 \%$ and in Casal di Principe around 55\%. Analysing the revenues per capita, in Giugliano these are three times more than in Casal di Principe, with this being a useful indicator of a greater attention from the Local Authority of Giugliano in contrasting the unauthorized buildings phenomenon. In other words, analysing the entity of the revenues, this municipality expresses a greater effort in legalising the phenomenon.

The decrease of revenues aimed to realise public facilities is accompanied by a reduction of expenditure for investments (capital expenditures); in the last years, it is possible to verify a contraction in the functions concerning urban planning and territorial and environmental management. Looking at Table 6, in Giugliano the expenditures guaranteeing the management of the territory and environment, in the triennium analysed, is on average 256 euro per capita, with a reduction in 2012; analysing the voices in detail, it is possible verify that the capital expenditure for urban planning and territory are relevant only in 2011, while the current expenditures for the waste management are the most considerable in all three years, more than $60 \%$ of the total expenditure. This data is verified in many other municipalities, with that of waste being a serious problem in Campania Region. With reference to Table 7, in Casal di Principe the expenditure for the management of the territory and environment are less than in Giugliano, on average 220 euro per capita, with there also being a reduction in 2012. 
Table 6: Giugliano expenditures for the Territory and Environment.

\begin{tabular}{|l|c|c|c|c|c|c|c|c|c|}
\hline \multirow{2}{*}{ Expenditures } & \multicolumn{3}{c|}{ 2012 } & \multicolumn{3}{c|}{ 2011 } & \multicolumn{3}{c|}{2010} \\
\cline { 2 - 10 } & Total & per capita & capital & Total & per capita & capital & Total & per capita & capital \\
\hline Territory and Environment & 28.604 .825 & 238 & 588.835 & 31.757 .441 & 266 & 1.702 .428 & 31.044 .710 & 264 & 1.500 .000 \\
- Urban planning and Territory & 904.796 & 7 & 171.351 & 1.444 .328 & 12 & 448.287 & 1.157 .781 & 10 & 450.108 \\
- Social Housing & - & - & - & - & - & & - & - & - \\
- Civil protection & 29.815 & 1 & - & 1.298 & 0 & - & 67.535 & 1 & - \\
- Water service & 9.381 .300 & 78 & 337.339 & 11.134 .729 & 93 & 193.538 & 6.646 .140 & 57 & 831.231 \\
- Waste & 17.473 .313 & 145 & - & 17.683 .987 & 148 & 98.445 & 22.067 .060 & 187 & - \\
- Parks & 815.602 & 7 & 80.145 & 1.493 .099 & 13 & 962.158 & 1.106 .194 & 9 & 236.827 \\
\hline
\end{tabular}

Table 7: Casal di Principe expenditure for the Territory and Environment.

\begin{tabular}{|l|c|c|c|c|c|c|c|c|c|}
\hline \multirow{2}{*}{ Expenditures } & \multicolumn{3}{c|}{$\mathbf{2 0 1 2}$} & \multicolumn{3}{c|}{$\mathbf{2 0 1 1}$} & \multicolumn{3}{c|}{$\mathbf{2 0 1 0}$} \\
\cline { 2 - 10 } & Total & per capita & capital & Total & per capita & capital & Total & per capita & capital \\
\hline Territory and Environment & 3.810 .204 & 178 & 1.693 .077 & 5.993 .054 & 279 & 3.844 .690 & 4.534 .016 & 213 & 1.506 .260 \\
- Urban planning and Territory & 1.867 .993 & 87 & 1.693 .077 & 3.404 .378 & 158 & 3.384 .785 & 1.425 .513 & 68 & 1.300 .000 \\
- Social Housing & - & - & - & 11.571 & 1 & 11.571 & 156.311 & 7 & - \\
- Civil protection & 6.183 & 1 & - & 49.692 & 2 & - & 41.543 & 2 & - \\
- Water service & 86.333 & 4 & - & 57.037 & 3 & - & 74.988 & 3 & - \\
- Waste & 1.849 .695 & 86 & - & 2.022 .042 & 94 & - & 2.798 .267 & 130 & 12.846 \\
- Parks & - & - & - & 448.334 & 21 & 448.334 & 37.394 & 2 & 37.103 \\
\hline
\end{tabular}

The most substantial expenditures are for urban planning and territory (particularly in 2011) and waste management, while there is very little for the maintenance of green spaces. Comparing the revenues from building permits and sanctions with the total expenditures (year 2011 and 2012), it emerges how in Giugliano the ratio is approximately the $15 \%$, while in Casal di Principe, it is approximately 5\%. This means that there, the Local Authority, either releases few building permits or, more probably (considering the entity of the phenomenon in this territory) is very weak in contrasting it through sanctions.

\section{Concluding remarks}

The production of the sustainable city requires resources, interest and actors; in a situation of economic-financial scarcity, even the revenues with specific destinations (the constrained funds) as well as those from the retrospective building permits, assume a growing relevance in the municipal budgets, obliging local authorities to work in a perspective of greater efficiency and effectiveness in the management of informal settlements.

The synthetic exploration of the two municipal budgets showed above represents a further step of a research that, obviously, needs of a wider sample, extended to many others municipalities, clustered in function of the demographic dimensions. Considering the severe situation of informal settlements and unauthorized buildings in the Campania Region, a more systematic investigation of the voices that constitute the municipal budgets, with specific reference to the revenues deriving from the retrospective building permits as well as the capital expenditures, will helps to better understand and evaluate the behaviour of local authorities, regarding their capability both in the recovery of sanctions and investment programming. Obviously a greater recovery of resources should correspond to greater capital expenditure to the advantage of community.

In this perspective, it is useful to conclude recalling the point IV of the "Vienna Declaration on Informal Settlements in South Eastern Europe", endorsed in 2004: "Sustainable urban management requires that informal settlements be integrated in the social and economic, spatial/physical and legal 
framework, particularly at local level; successful regularisation efforts contribute to long-term economic growth as well as to social equity, cohesion and stability".

\section{References}

[1] United Nation, World Urbanization Prospect, The 2014 Revision, United Nations, New York, p. 2, 2014.

[2] European Environment Agency, SOER 2015 - The European environment state and outlook 2015, www.eea.europa.eu/soer, 2015.

[3] Potsiou C., Informal Urban Development in Europe. Experiences from Albania and Greece, summary version, UN-HABITAT, 2010.

[4] Allen A., You N., Sustainable Urbanisation: Bridging the Green and Brown Agendas, UCL Development Planning Unit in collaboration with DFID and UN-Habitat, London, 2002.

[5] Allen, A., Sustainable cities or sustainable urbanization, UCL's journal of sustainable cities, www.ucl.ac.uk/sustainable-cities, 2009.

[6] De Soto, H., The Mystery of Capital: Why Capitalism Triumphs in the West and Fails Elsewhere, Basic Books, New York, 2000.

[7] Economic Commission for Europe, In Search for Sustainable Solutions for Informal Settlements in the ECE Region: Challenges and Policy Responses, unedited draft, Geneva, 2008, p. 14.

[8] ISPRA, Il consumo di suolo in Italia, ISPRA, Italy www.isprambiente.gov.it, 2014, p. 52.

[9] ISTAT-CNEL, Il benessere equo e sostenibile in Italia, ISTAT, 2014.

[10] Forte C., La stima della sanzione pecuniaria per opere abusivamente eseguite, in Rivista del Catasto e dei Servizi Tecnici Erariali, anno XXVnn.4-5-6, Roma, 1970.

[11] United Nations, Self-made Cities, In Search of Sustainable Solutions for Informal Settlements in the United Nations, Economic Commission for Europe Region, New York and Geneva, 2009, p. 15.

[12] Defrancesco E., Gatto P., Rosato P., Bozzolan I., The valuation of Environmental Damage Compensation: An Integrated Framework, in Rivista SIEV (Società Italiana di Estimo e Valutazione), n. 9, Dei, Roma, Italy, 2012.

[13] Forte F., 'Il finware per l'umanizzazione della città', in (eds): Fusco Girard L., Forte B., Cerreta M., De Toro P., Forte F., L'uomo e la città. Verso uno sviluppo umano e sostenibile, Franco Angeli, Milano, 2003.

[14] UN-HABITAT, Guide to Municipal Finance, Nairobi, 2009.

[15] Forte F., Illegal Buildings and Local Finance in New Metropolitan Perspectives, in (eds): Bevilacqua, C., Calabrò F., Della Spina L., New Metropolitan Perspectives. Advanced Engineering Forum, vol. 11, www.scientific.net, 2014, pp. 600-606.

[16] De Biase C., Forte F., Unauthorised building and financial recovery of urban areas: evidences from Caserta Area, in 6th EuroMed Conference book of proceedings, EuroMed Press, Estoril, Portugal, 2013, pp. 816-831. 